\title{
CHARACTERISTICS AND TREATMENT OF COAGULOPATHY ASSOCIATED WITH COVID-19
}

\section{KARAKTERISTIKE I LEČENJE KOAGULOPATIJE UDRUŽENE SA COVID-19}

\author{
Predrag Miljić $c^{1,2}$ \\ ${ }^{1}$ Univerzitetski klinički centar Srbije, Klinika za hematologiju, Beograd, Srbija \\ ${ }^{2}$ Univerzitet u Beogradu, Medicinski fakultet, Beograd, Srbija \\ Correspondence: predragmiljic@yahoo.com
}

\section{Abstract}

Coagulopathy in COVID-19 represents a thrombo-inflammatory condition, and it is one of the most important causes of morbidity and mortality in this disease. The occurrence of coagulopathy correlates with the intensity of the inflammatory response to SARS-Cov-2 virus infection, and its presence is characterized by laboratory markers of blood hypercoagulability and clinically pronounced prothrombotic condition. Although the mechanism of coagulopathy is not fully elucidated, dysregulated and overemphasized immune responses mediated by inflammatory cytokines, complement activation, leukocyte activation with release of free nucleic acids and histones into the circulation, hypoxia and endothelial damage play a very important role in its development. Thrombosis can occur in all parts of the circulatory system and is most often localized in the microcirculation and venous part of the vasculature. A number of studies have shown that the presence of thrombotic pulmonary embolism can be demonstrated by objective methods in approximately 15\% of COVID-19 patients treated in intensive care units, while the incidence of total venous thromboembolism in this group of patients is over $20 \%$ despite antithrombotic prophylaxis. Although much less common than venous thrombosis, arterial thrombosis may also occur in COVID-19 patients, most often in the form of myocardial infarction, ischemic stroke and peripheral artery occlusion. Damage to the endothelium under the influence of virus or inflammatory response, activation of platelets and coagulation system with fibrin deposition leads to extensive thrombosis in the microcirculation of lungs and other tissues and directly contributes to respiratory failure, ARDS or multiorgan failure. Therefore, coagulopathy in COVID-19 is an integral part of the pathophysiological mechanism of the disease and contributes to its clinical manifestation and progression. Main laboratory characteristics of COVID-19 coagulopathy are elevated values of D-dimer in the blood, which occurs in the process of decomposition of precipitated fibrin under the action of fibrinolytic enzymes in the microcirculation of the lungs and other organs. Therefore, D-dimer values reflect the intensity of the inflammation in the lungs and have prognostic significance in recognizing patients at risk of serious complications and unfavorable course of the disease.

Keywords:

COVID-19,

coagulopathy,

thrombosis,

D-dimer,

anticoagulants In contrast to disseminated intravascular coagulation in sepsis, severe thrombocytopenia and hypofibrinogenemia as well as bleeding tendencies are rare in COVID-19 coagulopathy. Due to the high frequency and important role of coagulopathy in morbidity and mortality, the use of anticoagulant therapy is recommended in all hospitalized patients. However, the optimal way of treating coagulopathy and the intensity of antithrombotic prophylaxis are not known, and represent the subject of intensive research. 


\section{Sažetak}

Koagulopatija udružena sa COVID-19 predstavlja tromboinflamatorno stanje i jedan je od najvažnijih uzroka morbiditeta i mortaliteta u ovoj bolesti. Pojava koagulopatije korelira sa intenzitetom inflamatornog odgovora na infekciju SARS-Cov-2 virusom, a njeno prisustvo se karakteriše laboratorijskim pokazateljima hiperkoagulabilnosti krvi i klinički izraženim protrombogenim stanjem. Iako mehanizam koagulopatije nije potpuno razjašnjen, smatra se da disregulisani i prenaglašeni imunološki odgovor posredovan inflamatornim citokinima, aktiviranje komplementa, aktiviranje leukocita sa oslobađanjem slobodnih nukleinskih kiselina i histona u cirkulaciju, hipoksija i oštećenje endotela imaju veoma važnu ulogu u njenom nastanku i progresiji. Tromboze se mogu javiti u svim delovima cirkulatornog sistema, pri čemu su najčešće lokalizovane u mikrocirkulaciji pluća i venskom delu vaskulature. U većem broju studija je pokazano da se prisustvo tromboembolije pluća može dokazati objektivnm metodama kod približno 15\% COVID-19 bolesnika koji se leče u jedinicama intenzivne nege, dok je učestalost ukupnog venskog tromboembolizma u ovoj grupi bolesnika preko $20 \%$ uprkos primeni antitrombozne profilakse. Iako znatno ređe u odnosu na trombozu vena, kod COVID-19 bolesnika javljaju se $\mathrm{i}$ tromboze $\mathrm{u}$ arterijskom sistemu, najčešće u vidu infarkta miokarda, ishemijskog šloga i okluzije perifernih arterija. Oštećenje endotela pod dejstvom virusa ili inflamatornog odgovora, aktiviranje trombocita i koagulacionog sistema sa taloženjem fibrina dovode do opsežnih tromboza u mikrocirkulaciji pluća i drugih tkiva i direktno doprinose pojavi respiratorne insuficijencije, akutnog respiratornog distres sindroma (ARDS) ili funkcionalne slabosti drugih organa. Stoga koagulopatija u COVID-19 predstavlja integralni deo patofiziološkog mehanizma bolesti i doprinosi njenom kliničkom ispoljavanju i progresiji. Osnovna laboratorijska karakteristika COVID-19 koagulopatije su povišene vrednosti $\mathrm{D}$-dimera u krvi, koji nastaje u procesu razgradnje istaloženog fibrina pod dejstvom fibrinolitičkih enzima u mikrocirkulaciji pluća i drugih organa. Zbog toga vrednosti D-dimera odražavaju intenzitet inflamatornog dogovora u plućima i imaju prognostički značaj u prepoznavanju bolesnika sa rizikom od pojave ozbiljnih komplikacija i nepovoljnog toka bolesti. Za razliku od diseminovane intravaskularne koagulacije u sepsi,

Ključne reči:

COVID-19,

koagulopatija,

tromboza,

D-dimer, antikoagulansi teška trombocitopenija i hipofibrinogenemija, kao i klinički ispoljena sklonost krvarenju, retke su u COVID-19 koagulopatiji. Zbog visoke učestalosti i važne uloge koagulopatije u morbiditetu i mortalitetu, primena antikoagulantne profilakse je preporučena kod svih hospitalizovanih COVID-19 bolesnika. Međutim, optimalan način lečenja koagulopatije i intenzitet antitrombozne profilakse nisu još uvek definisani i predstavljaju u ovom momentu predmet intenzivnih istraživanja.

\section{Uvod}

Bolest COVID-19, uzrokovana novim Corona virusom SARS-CoV-2 (engl. Severe acute respiratory syndrome corona virus-2), prvi je put registrovana krajem 2019. godine u kineskoj provinciji Hubei i u narednom periodu se u formi pandemije brzo raširila po čitavom svetu. Iako približno $80 \%$ obolelih ima blagu ili srednje tešku kliničku sliku, značajan procenat bolesnika reaguje hiperinflamatornim odgovorom i izraženim protrombotskim stanjem. Teška klinička slika (dispneja, hipoksija, zahvatanje više od $50 \%$ plućne površine na snimku pluća) razvije se kod oko $15 \%$ bolesnika, a kod dodatnih 5\% obolelih javlja se kritično teška bolest sa respiratornom insuficijencijom, šokom ili slabošću većeg broja organa. Prema podacima Svetske zdravstvene organizacije, ukupna smrtnost u globalnim razmerama od COVID-19 je $2,2 \%$ (1). Interesantno je da kod značajnog broja bolesnika sa težim oblicima bolesti mogu biti zahvaćeni i drugi organi izvan respiratornog sistema. Poremećaji laboratorijskih parametara koji odražavaju funkciju hemostaznog sistema i veća učestalost tromboembolijskih komplikacija kod bolesnika sa COVID-19 opisani su od strane kineskih autora još na samom početku pandemije, a potvrđeni i u kasnijim studijama. Koagulopatija, koja se javlja kod bolesnika sa COVID-19 (engl. COVID-19 associated coagulopathy, CAC), po svom karakteru predstavlja tromboinflamatorno stanje, koje se odlikuje istovremenim prisustvom pokazatelja inflamacije i povišene koncentracije markera hiperkoagulabilnosti krvi, uz izraženu sklonost tromboziranju (2). Iako ova koagulopatija po nekim svojim laboratorijskim karakteristikama liči na diseminovanu intravaskularnu koagulaciju, koja se viđa u sepsi ili drugim teškim infekcijama, CAC predstavlja poseban entitet sa drugačijom patogenezom i posebnim kliničkim manifestacijama. $\mathrm{Za}$ razliku od diseminovane intravaskularne koagulacije kod koje u kliničkoj slici dominira sklonost krvarenju, kod koagulopatije udružene sa COVID-19 krvarenja su retka, dok je učestalost tromboembolijskih komplikacija izrazito visoka uprkos primeni antitrombozne profilakse. Nop (Nopp) i saradnici su u jednom sistematičnom pregledu literature i meta-analizi učestalosti tromboembolizma 
saopštili prisustvo tromboze kod $22,7 \%$ kritično bolesnih osoba koje su lečene u jedinicama intenzivne nege i kod 7,9\% svih hospitalizovanih bolesnika sa COVID-19 (3). Pored toga, patohistološke studije kod bolesnika preminulih zbog COVID-19 pokazale su prisustvo opsežnih tromboza u mikrocirkulaciji pluća, ali i drugih organa, koje nastaju kao rezultat kompleksnog procesa oštećenja endotela i aktiviranja koagulacionog sistema (4). Prema tome, aktiviranje koagulacionog sistema i povećano stvaranje trombina kod bolesnika sa COVID-19 ne samo da je udruženo sa povećanim rizikom od nastanka arterijskih $\mathrm{i}$ venskih tromboza nego formiranje tromboze u mikrocirkulaciji i, sledstveno, kompromitovanje funkcije različitih organa predstavlja integralni deo patogeneze bolesti. Huang i saradnici su saopštili da su kod bolesnika koji su zahtevali prijem u jedinice intenzivne nege (JIN) vrednosti D-dimera (medijana $2,4 \mathrm{mg} / \mathrm{L}(0,6$ - 14,4)) bile značajno veće nego kod bolesnika sa blažom formom bolesti (medijana 0,5mg/L $(0,3-0,8), p=0,0042)(5)$. Kasnije su i drugi autori potvrdili da stepen koagulopatije korelira sa kliničkom težinom bolesti i većim mortalitetom, što najverovatnije predstavlja odraz pomenutog aktiviranja koagulacionog sistema u mikrocirkulaciji različitih organa, pre svega pluća (6). Jedna od bitnih karakteristika koagulopatije udružene sa COVID-19 je njen evolutivni karakter, posebno kod bolesnika koji imaju naglašen inflamatorni odgovor i težu formu bolesti. Tang i saradnici su opisali značajan porast $\mathrm{D}$-dimera u krvi, produženje protrombinskog vremena i pad vrednosti fibrinogena desetog i četrnaestog dana hospitalizacije kod bolesnika sa fatalnim ishodom, potencirajući važnost redovnog laboratorijskog monitoringa ovih parametara (7). Kod bolesnika kod kojih je vrednost D-dimera u krvi bila za više od 6 puta veća od gornje granice normalnog, primena heparina male molekulske mase značajno je redukovala mortalitet na 32,8\% u odnosu na 52,4\%, koliko je bio kod bolesnika koji nisu primali ovaj lek $(\mathrm{p}=0,017)(7)$. Zbog toga primena antikoagulantnih lekova kod CAC nema samo za cilj da prevenira pojavu arterijskih ili venskih tromboza, nego bi trebalo da utiče na tok bolesti sprečavanjem pojave imunotromboze u mikrocirkulaciji i razvoja disfunkcije organa, pre svega nastanak akutnog respiratornog distres sindroma (ARDS) u plućima. Međutim, u ovom momentu optimalan način lečenja CAC i uticaj primene antikoagulantnih lekova na morbiditet i mortalitet bolesnika sa COVID-19 nije još uvek potpuno jasan i predstavlja oblast veoma intenzivnog naučnog istraživanja.

Učestalost trombotskih komplikacija kod bolesnika sa COVID-19

Jedna od najupadljivijih karakteristika COVID-19 je velika varijabilnost kliničkog ispoljavanja, koje može da varira od asimptomatskih i blagih oblika koji se leče u kućnim uslovima do teških formi bolesti sa respiratornom insuficijencijom, za koje je neophodno lečenje u JIN. Pored toga, s obzirom na pandemijski karakter oboljenja i eksplozivan način širenja, bolest je zahvatila delove sveta sa različitim kapacitetima i stepenom organizacije zdravstvenih sistema. Zbog toga ne iznenađuje činjenica da su u literaturi prisutni različiti podaci o učestalosti arterijskih i venskih tromboza kod bolesnika sa COVID-19. Sasvim je razumljivo da su na varijabilnost ovih podataka mogli da utiču način selekcije bolesnika, faza bolesti, primena antiinflamatornih i antitromboznih lekova, kao i način dijagnostikovanja tromboze. Prema dosadašnjim saopštenjima, izgleda da rizik od tromboembolijskih komplikacija korelira sa kliničkom težinom bolesti, pri čemu je najveći kod bolesnika koji se leče u jedinicama intenzivne nege, posebno ukoliko se primenjuje mehanička ventilacija.

Učestalost trombotičnih komplikacija kod bolesnika $\mathrm{u}$ jedinicama intenzivne nege

U studiji francuskih autora, koji su analizirali grupu od 150 bolesnika sa COVID-19, prosečne dobi 63 godine, koji su hospitalno lečeni u JIN u martu 2020. godine, pojava venskog tromboembolizma je zabeležena kod $43 \%$ bolesnika, pri čemu je 16,7\% imalo tromboemboliju pluća. Svi bolesnici uključeni u ovu studiju dobijali su tromboprofilaksu, uglavnom heparinom male molekulske mase (LMW heparin), pri čemu je $70 \%$ imalo profilaktičke, a 30\% bolesnika terapijske doze leka. Kod 77 bolesnika kod kojih je COVID-19 bio udružen sa akutnim respiratornim distres sindromom učestalost plućne tromboembolije bila je $11,7 \%$, nasuprot učestalosti od 2,1\% kod 144 bolesnika sa ARDS koji nije bio uzrokovan COVID-19. Ovo je autore navelo na zaključak da su bolesnici sa COVID-19 u većem riziku od pojave tromboembolijskih komplikacija u odnosu na druge bolesnike u jedinici intenzivne nege i da je kod njih u profilaksi tromboembolijskih komplikacija potrebno primeniti terapijske doze antitromboznih lekova (8). U studiji sličnog dizajna analizirani su podaci za 184 bolesnika sa pneumonijom udruženom sa COVID-19 koji su lečeni $\mathrm{u}$ jedinicama intenzivne nege $\mathrm{u}$ tri holandske bolnice u aprilu 2020. godine. Svi bolesnici su dobijali najmanje standardnu dozu tromboprofilakse. Ukupna učestalost tromboembolijskih komplikacija je bila $31 \%$, pri čemu je prisustvo venskog tromboembolizma objektivno ustanovljeno kod 27\% (95\% CI 17 - 37\%), a arterijskih tromboza kod 3,7\% (95\% CI 0 - 8,2\%) bolesnika. Najčešća manifestacija venskog tromboembolizma je bila tromboembolija plućne arterije, koja je bila prisutna kod $81 \%$ bolesnika sa trombozom, odnosno kod $14 \%$ od ukupnog broja bolesnika (9). Prema tome, obe studije koje su analizirale podatke za najteže bolesnike sa COVID-19 koji su lečeni u jedinicama intenzivne nege u uslovima razvijenog zdravstvenog sistema pokazale su visoku učestalost tromboembolijskih komplikacija, pri čemu je učestalost tromboembolije pluća bila oko $15 \%$ uprkos primeni antitrombozne profilakse.

Učestalost trombotičnih komplikacija kod hospitalizovanih bolesnika

U dosadašnjim publikacijama učestalost tromboembolijskih komplikacija kod hospitalizovanih bolesnika sa COVID-19 koji ne zahtevaju prijem u JIN bila je značajno manja u odnosu na bolesnike koji zahtevaju 
intenzivniji način lečenja i nege. U opservacionoj, retrospektivnoj multicentričnoj studiji, koja je obuhvatila podatke za 1240 bolesnika prosečne starosti $64 \pm 17$ godina koji su hospitalno lečeni izvan JIN, učestalost objektivno potvrđene tromboembolije pluća (TEP) primenom kompjuterizovane pulmoangiografije (CTPA) bila je $8,3 \%$. Interesantno je da u ovoj studiji nije uočena povezanost između tradicionalnih faktora rizika i pojave venskog tromboembolizma. S druge strane, u multivarijantnoj analizi značajno veći rizik od tromboembolizma bio je prisutan kod bolesnika sa povišenim vrednostima C-reaktivnog proteina (OR 1,03; 95\% CI 1,01 - 1,04; p = $0,001)$ i kod bolesnika sa dužim vremenom između pojave simptoma i hospitalizacije (OR 1,02; 95\% CI 1,006 - 1,038; $\mathrm{p}=0,002)$. Nasuprot tome, primena profilaktičkih (OR 0,83; 95\% CI 0,79 - 0,85; p < 0,001) ili terapijskih doza antikoagulanasa (OR 0,87; 95\% CI 0,82 - 0,92, p $<0,001)$ bila je udružena sa manjim rizikom od pojave tromboembolije pluća (10). U studiji holandske grupe autora analizirani su podaci za 198 bolesnika iz jednog centra, pri čemu je 32\% bolesnika zahtevalo lečenje u JIN. Ukupna učestalost tromboembolijskih komplikacija kod bolesnika u JIN i kod bolesnika na odeljenju sedmog dana od prijema u bolnicu bila je 26\% (95\% CI, 17 - 37) vs. 5,8\% (95\% CI, 1,4 - 15), 14. dana 47\% (95\% CI, 34 58) vs. 9,2\% (95\% CI, 2,6 - 21) i 21. dana hospitalizacije $59 \%$ (95\% CI, 42 - 72) vs. 9,2\% (2,6 - 21), ukazujući na značajno veći rizik od tromboembolizma kod COVID-19 bolesnika sa težim formama bolesti. Pored toga, prisutvo tromboembolijskih komplikacija značajno je uticalo na smrtnost u ovoj grupi bolesnika (adjusted HR, 2,4; 95\% CI, 1,02 - 5,5) (11).

Tromboembolijske komplikacije kod ambulantnih COVID-19 bolesnika

Pojedinačni slučajevi tromboze vena ili arterija opisivani su kod COVID-19 bolesnika sa blažim formama bolesti koji su lečeni u kućnim uslovima, ali u literaturi nema dovoljno podataka o učestalosti tromboembolijskih komplikacija u ovoj grupi bolesnika. U jednoj studiji je ispitivana učestalost TEP kod nehospitalizovanih bolesnika sa COVID-19 kod kojih je posumnjano na ovu komplikaciju. Ukupno 72 bolesnika sa COVID-19 uzrokovanom pneumonijom upućeno je na CTPA, pri čemu je prisustvo TEP dokazano kod 18\% bolesnika. Prosečne vrednosti D-dimera su bile veće u grupi bolesnika sa dokazanom TEP u odnosu na bolesnike koji nisu imali ovu komplikaciju $(7,29$ vs. $3,29 \mu \mathrm{g} / \mathrm{ml}, \mathrm{p}=0,011)$. S druge strane, ove dve grupe bolesnika se nisu razlikovale u pogledu težine bolesti ili radioloških karakteristika virusne pneumonije (12). Rezultati ove studije su pokazali da je TEP dokazana kod gotovo petine bolesnika koji nisu bili hospitalizovani, a kod kojih je postojala klinička sumnja na ovu komplikaciju. Ovakav nalaz ukazuje na opravdanost primene objektivnih dijagnostičkih metoda čak i pri malom stepenu kliničke sumnje na venski tromboembolizam kod ambulantnih COVID-19 bolesnika u cilju pravovremenog prepoznavanja ove ozbiljne komplikacije.
Tromboze u arterijskom sistemu

Tromboze $\mathrm{u}$ arterijskom sistemu su ređe u odnosu na tromboze vena, ali se mogućnost njihove pojave ne treba potceniti. U velikoj studiji, koja je analizirala učestalost tromboza kod 3334 hospitalizovana COVID-19 bolesnika od kojih je 829 lečeno u JIN, prisustvo šloga je dokazano kod 1,6\%, a infarkta miokarda kod 8,9\% bolesnika. Prisustvo arterijskih tromboza je bilo udruženo sa većim mortalitetom (HR 1,99; 95\% CI 1,65 - 2,40). U ovoj studiji starija životna dob, muški pol, istorija koronarne bolesti, povišene vrednosti D-dimera i hispansko poreklo bili su udruženi sa većim rizikom od pojave arterijske tromboze (13). U grupi bolesnika iz Vuhana, od praćenih 214 hospitalizovanih bolesnika prosečne dobi 53 godine, šlog se javio kod 6 (2,8\%) bolesnika (14).

\section{Tromboze u mikrocirkulaciji}

Izražena trombotska mikroangiopatija u vaskulaturi pluća sa oštećenjem endotela i prisutnim fibrinskim depozitima u kapilarima i interćelijskim prostorima uočena je kod 45 - 100\% COVID-19 bolesnika sa fatalnim ishodom i naziva se ,difuzna pulmonarna intravaskularna koagulopatija“, kako bi se naglasila lokalizovana priroda tromboznog procesa $(15,16)$. U jednoj studiji prisustvo mikrotromboza u vaskulaturi pluća ustanovljeno je kod svih 12 bolesnika umrlih od COVID-19, pri čemu je u sedam slučajeva (58\%) nađeno i prisustvo tromboze u venama koja nije bila klinički prepoznata za života, a u četiri slučaja tromboembolija pluća je bila neposredni uzrok smrti (17). Ovakvi nalazi jasno ističu značaj tromboze kao uzroka smrti kod bolesnika sa COVID-19 i potrebe za ranom dijagnozom koagulopatije i njenim efikasnim lečenjem.

\section{Krvarenje u COVID-19}

Krvarenja kod bolesnika sa COVID-19 su znatno ređa u odnosu na tromboembolijske epizode, ali ipak mogu da predstavljaju ozbiljnu komplikaciju, pogotovo kod bolesnika koji dobijaju antitromboznu terapiju. U jednoj seriji od 25 bolesnika sa teškom formom COVID-19, koji su evaluirani zbog abnormalnog neurološkog nalaza, prisustvo intrakranijalne hemoragije je dokazano kod ukupno 3 bolesnika, pri čemu je kod 1 bolesnika hemoragija bila prisutna istovremeno sa ishemijskim lezijama (18). Ovakav nalaz upućuje na jasnu potrebu diferenciranja između ishemijskih i hemoragijskih lezija kod COVID-19 bolesnika sa šlogom, kao i na primenu antitrombozne terapije samo kada postoje jasne indikacije.

\section{Karakteristike koagulopatije u COVID-19}

Stepen koagulopatije korelira sa težinom kliničke slike COVID-19 i značajno doprinosi morbiditetu i mortalitetu ovih bolesnika (7). Osnovna laboratorijska karakteristika koagulopatije u COVID-19 je povišena vrednost D-dimera, koja je obično 2 - 5 puta veća od gornje granice normalnog kod bolesnika sa težim formama bolesti (19). D-dimer nastaje kao rezultat razlaganja fibrina pod dejstvom fibrinolitičkog enzima plazmina i njegova povišena 
vrednost je dokaz da je došlo do aktiviranja koagulacionog sistema, povećanog obrazovanja trombina i lokalizovane ili generalizovane konverzije fibrinogena $\mathrm{u}$ fibrin. Pored toga, relativno čest nalaz su povišene vrednosti fibrinogena, blago produženo protrombinsko vreme (PV) i blago do umereno snižen broj trombocita. Po ovim karakteristikama koagulopatija u okviru COVID-19 ne odgovara profilu klasične diseminovane intravaskularne koagulacije kod koje je trombocitopenija više izražena, a vrednosti fibrinogena gotovo po pravilu snižene. Tang i saradnici su ispitivali vrednosti koagulacionih parametara na prijemu kod 183 bolesnika sa COVID-19 i našli su prosečno više vrednosti D-dimera i nešto veću vrednost PT-a (izraženo u sekundama) kod bolesnika koji su umrli u odnosu na one koji su preživeli (7). Slične rezultate saopštili su i Guan i saradnici koji su povišene vrednosti D-dimera našli kod 46\% bolesnika sa COVID-19 koji su primljeni u bolnicu, pri čemu je u grupi bolesnika koji su umrli učestalost povišenih vrednosti D-dimera bila 59,6\%, a u grupi preživelih bolesnika 42,3\% (20).

Mada su pod dejstvom inflamatornih citokina vrednosti fibrinogena kod većine bolesnika sa COVID-19 inicijalno povećane, kod značajnog broja bolesnika sa nepovoljnim tokom bolesti dolazi do postepenog pada vrednosti fibrinogena, ukazujući na evoluciju koagulopatije u pravcu slike klasične diseminovane intravaskularne koagulacije. Tang i saradnici su našli značajno niže prosečne vrednosti fibrinogena kod bolesnika koji su umrli u odnosu na preživele bolesnike (7).

U krvi bolesnika sa teškom formom COVID-19 opisane su značajno povišene vrednosti FV, FVIII i von Vilebrandovog (von Willebrand) faktora (VWF) (21). Smatra se da povišene vrednosti VWF nastaju kao rezultat naglašenog otpuštanja ovog faktora iz Vajbel-Paladovih (Weibel-Palade) telašaca usled stimulacije i oštećenja endotelnih ćelija (22). Vrednosti plazminogena su takođe povišene kod bolesnika sa teškom formom bolesti, najverovatnije kao odraz taloženja fibrina u mikrocirkulaciji pluća i disfunkcifje fibrinolitičkog i koagulacionog sistema (23). U studiji koja je obuhvatila rezultate za 62 bolesnika sa blagom, srednje teškom i teškom kliničkom slikom, Pejvandi i autori su ustanovili gotovo linearnu korelaciju između povišenih vrednosti $\mathrm{D}$-dimera, koncentracije fibrinogena i VWF sa koncentracijom inflamatornih markera i kliničkim stepenom težine bolesti. Ovakvi nalazi takođe ukazuju na tesnu interakciju između inflamacije, oštećenja endotelnih ćelija i aktiviranja koagulacionog sistema, što rezultira potentnim tromboinflamatornim stanjem kod težih formi COVID-19 (24). Za razliku od potrošne koagulopatije u DIK-u, kod koje je trombocitopenija najsenzitivniji indikator njenog prisustva, značajnije smanjen broj trombocita je znatno ređi kod bolesnika sa COVID-19. U jednoj studiji na početku pandemije broj trombocita manji od $150 \times 10^{9} / \mathrm{L}$ nađen je kod $36,2 \%$ svih hospitalizovanih COVID-19 bolesnika i kod 57,7\% onih sa težom formom bolesti (20). S druge strane, kod bolesnika sa umereno teškom formom bolesti može biti prisutna trombocitoza, pri čemu je opisano da bolesnici sa povećanim brojem trombocita i limfopenijom zahtevaju duže hospitalno lečenje (25).

\section{Mehanizam nastanka koagulopatije u COVID-19}

Patogeneza koagulopatije udružene sa oboljenjem COVID-19 nije potpuno razjašnjena, ali, po svemu sudeći, u njenom nastanku i progresiji najveći značaj ima složena interakcija komponenti hemostaznog sistema sa elementima hiperinflamatornog odgovora koji prati ovu infekciju. Dobro je poznato da između mehanizama koji učestvuju $\mathrm{u}$ inflamaciji, s jedne strane, i koagulacionog sistema, s druge strane, postoje brojne dodirne tačke, tako da se ova dva važna procesa međusobno prepliću, deleći veći broj zajedničkih signalnih puteva. Štaviše, tromboza u sitnim krvnim sudovima u regiji inflamacije deo je nespecifičnog imunološkog odgovora u odbrani organizma od infekcije i naziva se imunotromboza (26). Ona ima važnu protektivnu ulogu sa ciljem da spreči širenje mikroba iz regije zahvaćene inflamacijom. Međutim, u slučaju prevelike stimulacije, kao što se to dešava u sepsi, može doći do neadekvatnog i ekscesivnog aktiviranja koagulacionog sistema i izvan regije inflamacije, sa pojavom sistemske hiperkoagulabilnosti krvi, što rezultira pojavom diseminovane intravaskularne koagulacije i poremećajem funkcije većeg broja organa (engl. multiple organ failure) usled tromboze u mikrocirkulaciji $(27,28)$. Smatra se da u procesu imunotromboze koja prati teške infekcije i inflamacije posebno važnu ulogu imaju nakupljanje i aktivacija neutrofila sa oslobađanjem nukleinskih kiselina i histona u cirkulaciju (tzv. NET-oza, engl. neutrophil extracellular trap). Slobodna DNA i histoni koji se osobađaju u regiji inflamacije iz aktiviranih neutrofila među glavnim su medijatorima imunotromboze tako što povećavaju stvaranje trombina, inhibiraju fibrinolizu i podstiču aktiviranje trombocita (29). Pretpostavlja se da infekcija SARSCoV-2 virusom može dovesti do hiperkoagulabilnosti krvi različitim mehanizmima, što može biti objašnjenje za ekstremnu varijabilnost u laboratorijskoj i kliničkoj ekspresiji oboljenja.

Virus najčešće napada epitelne ćelije pluća, endotelne ćelije krvnih sudova i limfocite, zbog čega su najčešće kliničke manifestacije teške COVID-19 bolesti ARDS, šok i koagulopatija (30). Po svemu sudeći, pod uticajem virusa i inflamatornog odgovora organizma kod značajnog broja bolesnika sa srednje teškom formom bolesti u plućima dolazi do oštećenja endotelnih ćelija, povećane vaskularne permeabilnosti i deponovanja fibrina u mikrocirkulaciji. Okluzija mikrocirkulacije fibrinskim trombima praćena je sekundarnim aktiviranjem fibrinolitičkog sistema koji je vrlo potentan u plućnom tkivu, što dovodi do formiranja D-dimera i fibrin-degradacionih produkata koji se ,prelivaju“ u krv u kojoj mogu biti prisutni u visokoj koncentraciji. Kod bolesnika sa najtežim oblicima COVID-19 dolazi do sistemskog hiperinflamatornog odgovora sa citokinskom olujom i potentnijim, sistemskim aktiviranjem hemostaznog sistema (31). 
Virus SARS-CoV-2 ulazi u ćeliju posredstvom interakcije sa $A C E-2$ receptorom, što dovodi do internalizacije $A C E-2$ receptora i remeti odnos između ACE-2 receptora i ACE na površini ćelijske membrane. Smatra se da poremećaj ovog odnosa može da inicira proces inflamacije, tromboze i poremećaja fibrinolize (32). Ključni događaj $\mathrm{u}$ procesu formiranja fibrina je aberantna ekspresija tkivnog faktora (TF) na membrani različitih ćelija koje dolaze u kontakt sa činiocima koagulacije i na taj način iniciraju proces koagulacije krvi. Pretpostavlja se da SARS-CoV-2 može dovesti do povećane ekspresije TF posredstvom najmanje tri potentna mehanizma: produkcije inflamatornih citokina, aktiviranja komplementa i oštećenja ćelija. Pokazano je da virusna RNA aktivira TLR-3 i 7 i na taj način stimuliše intraćelijski $N F-k B$ signalni put i faktore koji regulišu interferon (engl. interferon regulatory factors, IRFs), sa posledičnim povećanjem sinteze proinflamatornih citokina, posebno interferona gama, faktora tumorske nekroze alfa (TNFa), interleukina (IL) $1 \beta$, IL-2, IL-6, IL7, IL-8, IL-10, IL-17, makrofagnog inflamatornog proteina 1a i monocitnog hemoatraktantnog proteina 1 (MCP1) (5). Aktivacija imunološkog sistema i prisustvo inflamatornih citokina snažno stimulišu ekspresiju tkivnog faktora na membrani monocita/makrofaga. Povećana koncentracija IL-6 doprinosi hiperkoagulabilnosti krvi na taj način što zajedno sa IL-1 i TNFa potencira ekspresiju protrombogenih karakteristika endotela (27). Faktor tumorske nekroze alfa i angiotenzin II stimulišu povećanu ekspresiju tkivnog faktora na makrofazima i trombocitima. Oštećene ćelije alveolarnog epitela takođe eksprimiraju tkivni faktor, što dovodi do aktiviranja koagulacionog sistema i lokalizovanog nakupljanja fibrina u predelu alveokapilarnog sistema (33). Za IL-8 je pokazanao da stimuliše nakupljanje neutrofila i proces oslobađanja slobodnih nukleinskih kiselina i histona u cirkulaciju koji, kako se danas shvata, obrazuju skelet za formiranje tromba (34). U trombima iz plućne mikrocirkulacije osoba koje su preminule od COVID-19 dokazano je prisustvo neutrofila, slobodnih nukleinskih kiselina i histona, što ukazuje da proces NET-oze igra važnu ulogu u taloženju fibrina u mikrocirkulaciji pluća i pojavi respiratornog distres sindroma kod ove bolesti (35). Osim povećane produkcije inflamatornih citokina, SARS$\mathrm{CoV}-2$ uzrokuje aktiviranje komplementa sa obrazovanjem potentnih anafilotoksina C3a i C5a, od kojih C5a ima sposobnost da podstiče ekspresiju tkivnog faktora na endotelnim ćelijama i neutrofilima (36). U normalnim okolnostima postoji veoma koordinisana interakcija između činilaca koagulacije i fibrinolize sa sistemom komplementa koja omogućava održavanje precizne ravnoteže koagulacionog sistema. Generalno se smatra da u toku COVID-19 dolazi do poremećaja ovog odnosa, što može da rezultira razvojem tromboinflamatornog stanja (37).

\section{Lečenje koagulopatije udružene sa COVID-19}

Zbog kompleksne i još uvek nepotpuno razjašnjene patogeneze, uske povezanosti sa mortalitetom i morbiditetom, kao i nedovoljne količine podataka iz randomizovanih studija, lečenje koagulopatije udružene sa COVID-19 neretko predstavlja veoma izazovan zadatak za lekare koji zbrinjavaju ove bolesnike, posebno kada se radi o težim formama bolesti. Kao što je već pomenuto, lečenje CAC ima za cilj da prevenira pojavu tromboze u venama i arterijama, ali i da smanji morbiditet i mortalitet delujući na patogenezu imunotromboze. U tom smislu, treba napomenuti da heparin, kao osnovni lek u lečenju koagulopatije, ima i antiinflamatorni efekat i da je u prekliničkim studijama sa COVID-19 pokazao i antivirusno delovanje (38). Međutim, primena antitromboznih lekova, osim očekivanog pozitivnog efekta, može biti udružena i sa značajnim rizicima od krvarenja, pogotovo u uslovima prisutne koagulopatije. Pojava krvarenja ne predstavlja samo ozbiljnu komplikaciju, nego može da onemogući dalju primenu antikoagulantnih lekova i time značajno poveća rizik od tromboze. Zbog toga još uvek nema jedinstvenih stavova ni o indikacijama za primenu antitromboznih lekova, ni o njihovoj dozi kod bolesnika sa COVID-19. Do sada je nekoliko stručnih udruženja ili ekspertskih panela publikovalo preporuke za prevenciju tromboembolizma i primenu antitromboznih lekova kod bolesnika sa COVID-19, koje su uglavnom bazirane na ekspertskom mišljenju i rezultatima opservacionih studija $(39,40,41)$. Rezultati nedavne preliminarne analize nekoliko randomizovanih kontrolisanih studija (uključujući REMAP-CAP, ATTACC i ACTIV-4a), koje su koristile podatke sa elektronskih platformi, pokazali su da su kod hospitalizovanih bolesnika sa umereno teškom formom COVID-19 terapijske doze heparina bile nešto efikasnije u odnosu na standardnu tromboprofilaksu u produžavanju vremena bez potrebe za podrškom funkcije organa (mehaničke ventilacije) 21 . dana bolesti, sa nesignifikantnom redukcijom mortaliteta od 2\%. Međutim, kod najtežih bolesnika kod kojih je od početka hospitalizacije bila potrebna podrška funkcije organa, primena terapijskih doza leka nije uticala na ishod bolesti, ukazujući da ni visoke doze heparina ne utiču na uznapredovalu imunotrombozu. S druge strane, kod ovih bolesnika učestalost značajnih krvarenja bila je 3,1\% nasuprot 2,4\% kod bolesnika koji su dobijali standardnu tromboprofilaksu (42). U nedavno objavljenim rezultatima INSPIRATION kliničke studije, ukupno 562 bolesnika lečena u JIN, randomizovana su da dobijaju intermedijarne doze ili standardne doze heparina za tromboprofilaksu. Između ove dve grupe nije registrovana značajna razlika u učestalosti epizoda tromboze arterija ili vena, učestalosti potrebe za ekstrakorporalnom membranskom ventilacijom ili ukupnom mortalitetu u prvih 30 dana hospitalizacije. Međutim, u grupi bolesnika koji su lečeni intermedijarnim dozama heparina zabeležena je veća učestalost kako velikih krvarenja (2,5\% vs. 1,4\%), tako i klinički značajnih krvarenja $(4,3 \%$ vs. $1,7 \%)$ u odnosu na grupu lečenu standardnom tromboprofilaksom (43). Prema tome, iako su ranije opservacione studije ukazivale na korist od većih doza heparina, rezultati skorašnjih randomizovanih studija nisu u potpunosti u skladu sa takvim nalazima. Pored heparina, u lečenju CAC se primenjuju i drugi antitrombozni lekovi, ali još uvek nema jasnih 
preporuka o njihovoj upotrebi. Mazliš (Meizlish) i saradnici su pokazali da je primena acetil-salicilne kiseline bila udružena sa znatno manjim kumulativnim mortalitetom u COVID-19 bolesnika (HR = 0,522 (0,336 - 0,8129, p = $0,004)(44)$. U tom polgedu se očekuju rezultati primene aspirina u velikim randomizovanim studijama.

Prema današnjim shvatanjima koja preovlađuju u stručnoj literaturi i prema preporukama relevantnih stručnih udruženja, profilaksa tromboembolizma je indikovana kod svih hospitalizovanih bolesnika sa COVID-19 koji imaju opšte medicinske, hirurške ili opstetricijske probleme ukoliko nema specifičnih kontraindikacija za njenu primenu, kao što su značajna krvarenja u prethodnih $48 \mathrm{~h}$. Iako se profilaksa generalno ne preporučuje nakon završenog hospitalnog lečenja, izgleda da rizik od tromboembolizma nije zanemarljiv ni u toj grupi bolesnika.

Primena profilakse tromboembolizma kod hospitalizovanih bolesnika

Za bolesnike koji se leče u JIN najčešće se preporučuje profilaktička doza heparina, a samo u pojedinačnim slučajevima kao što je, na primer, sumnja na postojanje tromboze vena koja se ne može dokazati objektivnim metodama, opravdano je primeniti veće (intermedijarne ili terapijske) doze antikoagulantnih lekova $(40,41)$. Treba imati na umu da kod bolesnika koji se leče u JIN mogu postojati i drugi poremećaji hemostaznog sistema ili drugi faktori koji povećavaju rizik od krvarenja koje treba uzeti u obzir pri odluci o uvođenju i dozi antikoagulantnih lekova. Za hospitalizovane bolesnike koji ne zahtevaju prijem u JIN preporučuje se primena profilaktičkih doza heparina. Generalno se smatra da koncentracija D-dimera u krvi, čije su povišene vrednosti najčešća laboratorijska manifestacija CAC, ne bi trebalo da utiče na odluku o uvođenju i dozi antitrombozne terapije.

Primena profilakse tromboembolizma po završetku hospitalnog lečenja

U literaturi nema mnogo podataka o učestalosti tromboembolizma kod COVID-19 bolesnika po završetku hospitalnog lečenja. Do sada nisu publikovane randomizovane studije o primeni antitrombozne profilakse kod bolesnika koji se leče u vanbolničkim uslovima. U jednoj opservacionoj studiji je praćeno 4.906 bolesnika sa COVID-19 nakon otpusta iz bolnice i nađena je incidencija venskog tromboembolizma od 1,6\% (45). U ovoj studiji je ustanovljeno da su starija životna dob, hronična bolest bubrega, koronarna bolest srca, boravak u JIN i IMPROVE$D D$ skor za venski tromboembolizam $\geq 4$ bili udruženi sa većim rizikom od pojave tromboembolijskih komplikacija nakon završetka hospitalnog lečenja. S obzirom na to da studija nije bila randomizovana, antitrombozna profilaksa je primenjena na osnovu individualne kliničke procene i nezavisne odluke nadležnog lekara kod ukupno 13\% bolesnika. Kod njih je zabeleženo smanjenje rizika od tromboze za $46 \%$ u odnosu na bolesnike koji nisu dobijali profilaksu. Prema tome, kod bolesnika sa prisutnim dodatnim faktorima rizika za trombozu, kao što je podatak o ranijim epoizodama tromboembolizma, skorašnjim hirurškim operacijama, povredama ili snažnim trombofilnim stanjima ima smisla primeniti profilaktičku terapiju u trajanju od nekoliko nedelja nakon završenog hospitalnog lečenja. U tu svrhu se mogu koristiti lekovi primenjivani u kliničkim studijama, kao što je rivaroksaban u dozi od $10 \mathrm{mg}$ na dan (46). Rutinsko određivanje D-dimera po završenom hospitalnom lečenju i ordiniranje antitrombozne profilakse samo na osnovu rezultata ovog parametra ne preporučuje ni jedno stručno udruženje u dosadašnjim publikacijama. Međutim, određivanje D-dimera ima smisla u slučaju kliničke sumnje na prisustvo tromboembolizma i, ako su prisutne povišene vrednosti treba objektivnim metodama isključiti postojanje tromboze vena.

Profilaksa venskog tromboembolizma kod bolesnika koji nisu hospitalizovani

Veoma malo se zna o učestalosti tromboembolijskih komplikacija kod bolesnika sa COVID-19 koji su imali blagu formu bolesti i koji nisu bili hospitalizovani za vreme trajanja bolesti. Većina ekspertskih mišljenja, kao i do sada publikovana saopštenja stručnih udruženja ne preporučuju rutinsku profilaksu tromboembolizma niti rutinsko određivanje D-dimera u ovoj grupi bolesnika $(40,41)$. Odluka o praćenju vrednosti D-dimera, kao i o eventualnom uvođenju profilaktičke terapije treba da bude zasnovana na individualnoj proceni kliničkog stanja bolesnika. Iako kod najvećeg broja bolesnika iz ove grupe rutinska profilaksa nije potrebna, kod bolesnika sa povećanim rizikom od tromboembolizma, kao što su bolesnici sa prethodnom trombozom vena, bolesnici sa imobilizacijom ili bolesnici sa poznatim snažnim trombofilnim stanjima mogu biti kandidati za razmatranje primene antitrombozne profilakse.

\section{Literatura}

1. WHO. WHO Coronavirus Disease (COVID-19) Dashboard. 2021. (Internet). Available from: https://covid19.who.int/.

2. Connors JM, Levy JH Thromboinflammation and the hypercoagulability of COVID-19. J Thromb Haemost. 2020; 18(7):1559.

3. Nopp S, Moik F, Jilma B, Pabinger I, Ay C. Risk of venous thromboembolism in patients with COVID-19: A systematic review and meta-analysis. Res Pract Thromb Haemost. 2020; 4(7):1178-91.

4. Magro C, Mulvey JJ, Berlin D, Nuovo G, Salvatore S, Harp J, et al. Complement associated microvascular injury and thrombosis in the pathogenesis of severe COVID-19 infection: a report of five cases. Translational research : the journal of laboratory and clinical medicine. 2020; S1931-5244(20)30070-0.

5. Huang C, Wang Y, Li X. Clinical features of patients infected with 2019 novel coronavirus in Wuhan, China. Lancet. 2020; 395:497-506.

6. Fogarty H, Townsend L, Ni Cheallaigh C, Bergin C, Martin-Loeches I, Browne P, et al. COVID-19 Coagulopathy in Caucasian patients. Br J Haematol. 2020; 189:1044-9.

7. Tang N, Li D, Wang X, Sun Z. Abnormal coagulation parameters are associated with poor prognosis in patients with novel coronavirus pneumonia. J Thromb Haemost. 2020; 18:844-7.

8. Helms J, Tacquard C, Severac F, Leonard-Lorant I, Ohana M, Delabranche X, et al. CRICS TRIGGERSEP Group (Clinical Research in Intensive Care and Sepsis Trial Group for Global Evaluation and Research in Sepsis). High risk of thrombosis in patients with severe SARS-CoV-2 infection: a multicenter prospective cohort study. Intensive Care Med. 2020; 46(6):1089. 
9. Klok FA, Kruip MJHA, van der Meer NJM, Arbous MS, Gommers DAMPJ, Kant KM, et al. Incidence of thrombotic complications in critically ill ICU patients with COVID-19. Thromb Res. 2020; 191:145.

10. Fauvel C, Weizman O, Trimaille A, Mika D, Pommier T, Pace N, et al. Critical COVID-19 France Investigators. Pulmonary embolism in COVID-19 patients: a French multicentre cohort study. Eur Heart J. 2020; 41(32):3058.

11. Middeldorp S, Coppens M, van Haaps TF, Foppen M, Vlaar AP, Müller MCA, et al. Incidence of venous thromboembolism in hospitalized patients with COVID-19. J Thromb Haemost. 2020; 18(8):1995.

12. Gervaise A, Bouzad C, Peroux E, Helissey C. Acute pulmonary embolism in non-hospitalized COVID-19 patients referred to CTPA by emergency department. Eur Radiol. 2020; 30(11):6170.

13. Bilaloglu S, Aphinyanaphongs $\mathrm{Y}$, Jones $\mathrm{S}$, Iturrate $\mathrm{E}$, Hochman J, Berger JS. Thrombosis in Hospitalized Patients With COVID-19 in a New York City Health System. JAMA. 2020; 324(8):799.

14. Mao L, Jin H, Wang M, Hu Y, Chen S, He Q, et al. Neurologic Manifestations of Hospitalized Patients With Coronavirus Disease 2019 in Wuhan, China. JAMA Neurol. 2020; 77(6):683-90.

15. McGonagle D, O’Donnell J, Sharif K, Emery P, Bridgewood C. Immune mechanisms of pulmonary intravascular coagulopathy in COVID-19 pneumonia. Lancet Rheumatol. 2020; 2:437-45

16. Carsana L, Sonzogni A, Nasr A, Rossi RS, Pellegrinelli A, Zerbi P, et al. Pulmonary postmortem findings in a series of COVID-19 cases from northern Italy: a two-centre descriptive study. Lancet Infect Dis. 2020; 20(10):1135-40.

17. Wichmann D, Sperhake JP, Lütgehetmann $M$, Steurer $S$ Edler C, Heinemann A, et al. Autopsy Findings and Venous Thromboembolism in Patients With COVID-19. Ann InternMed. 2020; 173:268-77.

18. Miesbach W, Makris M. COVID-19: coagulopathy, risk of thrombosis, and the rationale for anticoagulation. Clinical and Applied Thrombosis/Hemostasis. 2020; 26:1076029620938149.

19. Lippi G, Favaloro EJ. D-dimer is Associated with Severity of Coronavirus Disease 2019: A Pooled Analysis. Thromb Haemost. 2020; 120(5):876-8.

20. Guan WJ, Ni ZY, Hu Y, Liang WH, Ou CQ, He JX, et al. Clinical Characteristics of Coronavirus Disease 2019 in China. New England Journal of Medicine. 2020; 382(18):1708-20.

21. Al-Ani F, Chehade S, Lazo-Langner A. Thrombosis risk associated with COVID-19 infection. A scoping review. Thrombosis research. 2020; 192:152-60.

22. Ward SE, Curley GF, Lavin M, Fogarty H, Karampini E, McEvoy NL, et al. Von Willebrand factor propeptide in severe coronavirus disease 2019 (COVID-19): evidence of acute andsustained endothelial cell activation. British Journal of Haematology. 2021; 192(4):714-9.

23. Whyte CS, Morrow GB, Mitchell JL, Chowdary P, Mutch NJ Fibrinolytic abnormalities in acute respiratory distress syndrome (ARDS) and versatility of thrombolytic drugs to treat COVID-19. J Thromb Haemost. 2020; 18:1548-55.

24. Peyvandi F, Artoni A, Novembrino C. Hemostatic alterations in COVID-19. Haematologica 2021; 106(5).

25. Qu R, Ling Y, Zhang YH, Wei LY, Chen X, Li XM, et al. Plateletto-lymphocyte ratio is associated with prognosis in patients with coronavirus disease $₫ 19$. Journal of medical virology. 2020; 92(9):1533-41

26. Engelmann B, Massberg S. Thrombosis as an intravascular effector of innate immunity. Nat Rev Immunol. 2013; 13(1):34-45.

27. Levi M, van der Poll T. Coagulation and sepsis. Thromb Res. 2017; 149:38-44.

28. Schouten M, Wiersinga WJ, Levi M, van der Poll T. Inflammation, endothelium, and coagulation in sepsis. J Leukoc Biol. 2008; 83(3):536-45.
29. Gould TJ, Lysov Z, Liaw PC. Extracellular DNA and histones: double-edged swords in immunothrombosis. J Thromb Haemost 2015; 13(1):S82-91.

30. Wang $\mathrm{D}, \mathrm{Hu} \mathrm{B}, \mathrm{Hu} \mathrm{C}$. Clinical characteristics of 138 hospitalized patients with 2019 novel coronavirus-infected pneumonia in Wuhan, China. JAMA. 2020; 323(11):e201585.

31. Siddiqi HK, Mehra MR. COVID-19 illness in native and immunosuppressed states: A clinical-therapeutic staging proposal. J Heart Lung Transplant. 2020; 39(5):405-407.

32. Henry BM, Vikse J, Benoit S, Favaloro EJ, Lippi G. Hyperinflammation and derangement of renin-angiotensin-aldosterone system in COVID-19: A novel hypothesis for clinically suspected hypercoagulopathy and microvascular immunothrombosis. Clin Chim Acta. 2020; 507:167-73.

33. Bautista-Vargas M, Bonilla-Abadia F, Canas CA. Potential role for tissue factor in thepathogenesis of hypercoagulability associated with in COVID-19. J Thromb Thrombolysis 2020; 50:479-83.

34. Laridan E, Martinod K, De Meyer SF. Neutrophil Extracellular Traps in Arterial and Venous Thrombosis. Semin Thromb Hemost. 2019; 45(1):86-93.

35. Middleton EA, He XY, Denorme F, Campbell RA, Ng D, Salvatore SP, et al. Neutrophil extracellular traps contribute to immunothrombosis in COVID-19 acute respiratorydistress syndrome. Blood. 2020; 136(10):1169-79.

36. Ritis K, Doumas M, Mastellos D. A novel C5a receptor-tissue factor cross-talk in neutrophils links innate immunity to coagulationpathways. J Immunol. 2006; 177:4794-4802.

37. Amara U, Rittirsch D, Flierl M. Interaction between the coagulation and complement system. In Adv Exp Med Biol. 2008; 632:71-79.

38. Wildhagen KCAA, García de Frutos P, Reutelingsperger CP, Schrijver R, Aresté C, Ortega-Gómez A, et al. Nonanticoagulant heparin prevents histone-mediated cytotoxicity in vitro and improves survival in sepsis. Blood. 2014; 123(7):1098-101.

39. Thachil J, Tang N, Gando S, Falanga A, Cattaneo M, Levi M, et al. ISTH interim guidance on recognition and management of coagulopathy in COVID-19. J Thromb Haemost. 2020; 18(5):1023.

40. Cuker A, Tseng EK, Nieuwlaat R. American Society of Hematology 2021 guidelines on the use of anticoagulation for thromboprophylaxis in patients with COVID-19. Blood Adv. 2021; 5(3):872.

41. Moores LK, Tritschler T, Brosnahan S, Carrier M, Collen JF, Doerschug K, et al. Prevention, Diagnosis, and Treatment of VTE in Patients With Coronavirus Disease 2019: CHEST Guideline and Expert Panel Report. Chest. 2020; 158(3):1143.

42. Zarychanski R. Therapeutic Anticoagulation in Critically Ill Patients with COVID-19 -Preliminary Report. medRxiv. 2021; 2021.03.10.21252749.

43. Sadeghipour P, Talasaz AH, Rashidi F, Sharif-Kashani B, Beigmohammadi MT, Farrokhpour M, et al. Effect of IntermediateDose vs Standard-Dose Prophylactic Anticoagulation on Thrombotic Events, Extracorporeal Membrane Oxygenation Treatment, or Mortality Among Patients With COVID-19 Admitted to the Intensive Care Unit: The INSPIRATION Randomized Clinical Trial. Jama 2021; 325(16):1620-30.

44. Meizlish ML, Goshua G, Liu Y, Fine R, Amin K, Chang E, et al. Intermediate-dose anticoagulation, aspirin, and in-hospital mortality in COVID-19: A propensity scorematched analysis. Am J Hematol. 2021; 96(4):471-9.

45. Giannis D, Allen SL, Tsang J. Postdischarge thromboembolic outcomes and mortality of hospitalized patients with COVID-19: the CORE-19 registry. Blood. 2021; 137(20):2838.

46. Hematology. COVID-19. (Internet). (cited 21. April, 2020.) Available from: https://www.hematology.org/COVID-19/ COVID-19-and-vte-anticoagulation. 